obviously had to struggle frequently with an excess of material, and although they have endeavoured to gain space by references to original papers, the surgical section would have been rendered more satisfactory if the compression had not been quite so rigid. Although somewhat unequal, this book will prove useful to those who desire to obtain a trustworthy guide to the medical and surgical diseases of children.

The Causation of Disease. By HaRry CaMpbelL, M.D., B.S. London : H. K. Lewis. 1889.

THE author of this highly ingenious essay has undertaken a task the difficulties of which are obvious. To attempt to reduce to order and place under the operation of natural law the multifarious circumstances and conditions which co-operate to produce what we term "disease" might well daunt the boldest. The chief obstacle to such an achievement lies in the fact that disease is no longer regarded as an entity, but that we have to deal with diseases, rather than "disease," and that each individual case has its own peculiarities of environment and structure, which not only modify the course taken by the disease, but also influence its occurrence. Dr. Campbell is not unmindful of such considerations, and he develops his argument with care and circumspection, analysing the internal and external influences that operate in determining the type of structure in a manner which cannot but command attention. In the twenty-first chapter of Part I., in which he sums up the long-sustained argument adduced from the study of the organism and its environment, he says truly that the pathologist in dealing with cause can do no more than state conditions; and, reducing the question to its simplest terms, he postulates disease as being constituted by an abnormal inter-reaction between the cell structure (S) and its environment $(\mathrm{E})$. The latter he points out is constituted by two elements-viz., that which results from the interaction between the several tissues composing the body, the internal environment; and secondly, that which is the result of the complex conditions, whereby the body is brought into relation with the external world. The important share taken by heredity in determining structure and in influencing the abnormal direction of morbid processes is dwelt on very fully. The interest of the book heightens as the author proceeds to discuss the operation of natural selection and sexual selection upon the occurrence and transmission of disease and the tendencies to it. The whole argument proves how fully the writer has assimilated the teachings of Darwin and Spencer, and applied them to elucidate many of the problems with which we are daily confronted. In showing the wide extension to be given to the great principle of evolution, and the doctrine of the survival of the fittest, the author of this work has opened up a vast field of thought which is both stimulating and suggestive. His pages demand careful study; the arguments he employs are based on the teachings of modern science, and although (owing doubtless to the intricacy of the subject) there are many repetitions and redundancies, he deserves much credit for so boldly grappling with the most abstruse of problems. We commend the essay to the thoughtful reader who is desirous of noting the extent to which the problems of disease can be solved by an appeal to natural laws.

WINDSOR AND ETON ROYal INFIRMARY.-Prince Christian presided at the annual meeting of this charity. The Dean of Windsor, in proposing a vote of thanks to the President, alluded regretfully to the loss sustained by the district through the absence of Princess Christian. Prince Christian, however, was able to afford the satisfactory intelligence that the Princess was progressing favourably, and would soon be restored to her usual health.

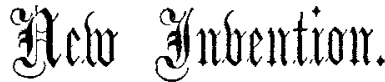

\section{A MODIFICATION IN THE BINAURAL STETHOSCOPE.}

Tre modification, which I trust will be found an improve. ment, consists (vide illustration) of a metal bifurcated con-

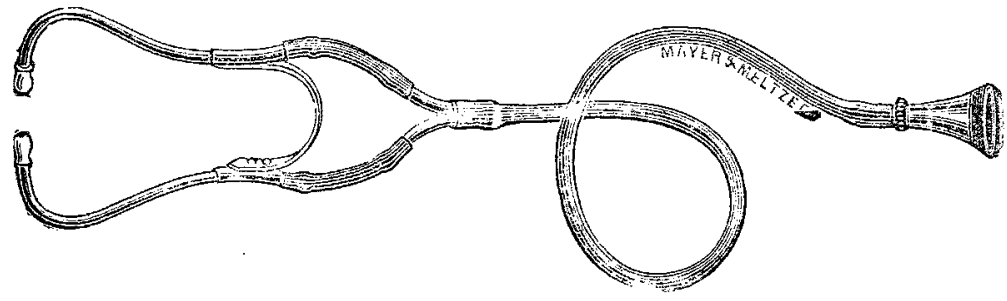

nector, uniting two short pieces of rubber tubing from the ear tubes with a single longer rubber tube leading down to an unbranched chest-piece.

FredK. C. Barker, M.D., F.R.C.S., Surgeon-Major, Bombay Medical Service, \&c。

\section{THE EXPENSES OF PRACTITIONERS IN GERMANY AND RUSSIA.}

Astonishment is frequently expressed in this country at the low fees obtained by continental medical men and the meagre salaries attached to such appointments as are held by them. It is, however, certain that in nearly all parts of the Continent, with the exception perhaps of some of the great cities and fashionable watering-places, the necessary cost of living and bringing up a family is very much less than it is in England. A communication from Dr. Tsezarevski has just been published in a Russian medical journal, in which he gives a synopsis of his average annual expenses for ten years, during which time he has held the posts of military surgeon, parochial medical ofticer, and railway surgeon. Thus he may probably be taken as a fairly typical Russian medical practitioner. During the ten years referred to-apparently the first ten years after he became qualified-his average annual expenses amounted to $£ 181$. These were made up in the following way:-1. Rent: heating, lighting, washing, and servants, £35. 2. Food, $£ 48$. 3. Clothes (excluding the children's), £25. 4. Furniture and repairs, £11. 5. Amusements, 113 . 6. Books, instruments, $£ 13$. 7. Children : clothes, education, books, toys, \&c., fl4. 8. Charity and presents, £11. 9. Travelling, £ll. With this he compares the average annual expenses of a German practitioner taken from a calculation published some time ago based on information obtained from a considerable number of gentlemen practising in Germany. The total amount in this case was put at $£ 167$, and was distributed under heads numbered as above in the following manner:-1. $£ 39$.

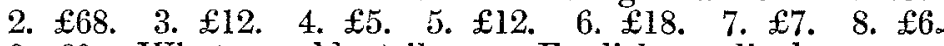
9. £0. What would strike an English medical man on looking at these accounts over and above the general lowness of the items is the extremely small cost of education and travelling. Of course, in Dr. Tsezarevski's case the children must all have been quite young, but how an average German practitioner can manage to dress and educate his children for $£ 7$ per annum is certainly somewhat mysterious. It is remarkable that no travelling expenses are put down for the Germans. That must surely imply, not that they are not incurred, but that they are met in some other way than from the practitioner's pocket. As at this time of year the general expenses of living and carrying on practice are apt to occupy a somewhat proninent position in the minds of most medical men, it may not be out of place to reproduce, for the purpose of comparison with the two scales of expenditure given, a rough estimate (suggested by a correspondent) which may be supposed to represent the expenses of an average English practitioner making $\$ 500$ per annum, grouped under the same headings as in the two continental scales :-1. $£ 100 . \quad 2 . £ 150.3 . £ 40.4 . £ 20 . \quad 5$. $£ 20$. 6. $£ 15$. 7. $£ 40$. 8. 215 . 9. $£ 70.10$ (drugs, bottles, \&c.). $£ 3 a$ 